\title{
A Review on Identification of Bacillus spp. using Molecular Characterization
}

\author{
Tamalika Sarangi* and S. Ramakrishnan
}

Department of Nematology, Centre for Plant Protection Studies, Tamil Nadu Agricultural University, Coimbatore - 641003, Tamil Nadu, India

*Corresponding author

Keywords

Bacillus spp, biochemical test, molecular technique.

\section{Article Info}

Accepted:

12 June 2016

Available Online:

10 July 2016
Nowadays the use of molecular tool is gaining importance for the proper and precise identification of any biological organisms. The technique is successfully adopted for the precise identification of Bacillus spp. The available literature on identification of Bacillus spp. at molecular level were collected and presented below. The review will be useful to the researchers working on this line as the identification of Bacillus spp. using morphological and cultural characters, biochemical tests etc. are time consuming, cumbersone and lacks precision.

\section{Introduction}

The endophytic bacteria, Bacillus spp. are generally classified based on their morphology and aggregation. The shape of the endophytic Bacillus spp. are spheres (coccus), rod shaped and round ended cylinders according to Wang et al.,(2008). Further the Bacillus spp. showing the cultural characters of colonization of bacteria on nutrient agar medium and serrated margin also used to identify the bacteria. (Hung and Annapurna, 2004 and Parvathi et al., 2004). Besides biochemical tests of employing the methods of simple staining, gram staining, utilization of citrate, catalase test, vogos proskaecur test, growth in Nacl, starch hydrolysis, methyl red test, growth at $4^{0} \mathrm{C}$ and $\mathrm{KOH}$ test are also in practise to identify the bacteria as Bacillus spp. (Rangasamy and Bagyaraj, 1993, Vetrivelkalai et al., 2010 and Manikandan and Muthuselvan, 2014).

\section{Molecular Characterization of Genus Bacillus}

For the precise identification of the endophytic genus various morphological, cultural and biochemical tests were performed as above. Since it is difficult to confirm the identity of the endophytes based on only morphological and biochemical characters as opined by Frietas et al., (2008), 
currently molecular techniques like t DNA PCR (tDNA-intergenic spacer length polymorphisms) and ITS-PCR analyses (16S-23S intergenic transcribed spacer region) are being used for the precise identification of the Bacillus endophytes.
Hence the information furnished on the identification of Bacillus spp. based on molecular characters in the Table will be useful as ready reference to researchers working on isolation and identification of the bacterium.

Table.1 Identification of Bacillus spp. using PCR technique

\begin{tabular}{|c|c|}
\hline Bacillus spp. & References \\
\hline Bacillus spp. & $\begin{array}{l}\text { Raton } \text { et al., (2012), Sihem } \text { et al., (2011), Absalon et al., (2012), } \\
\text { Ettoumi } \text { et al., (2013) }\end{array}$ \\
\hline B.amyloliquefaciens & $\begin{array}{l}\text { Wulff et al., (2002), Matarante et al., (2004), Lisboa et al., (2006), } \\
\text { Sarangi et al.(2009), Athukorala et al. ( 2009) }\end{array}$ \\
\hline B. anthracis & Hill et al.(2004) \\
\hline B.cereus & $\begin{array}{l}\text { Matarante } \text { et al.(2004), Hill } \text { et al. (2004), Nagesh } \text { et al. (2005), } \\
\text { Azokpota } \text { et al. (2007), Kang Cheng } \text { et al. (2009), Reddy et al. } \\
\text { (2009), Wahyudi et al. (2010), Oliveira } \text { et al. (2014) }\end{array}$ \\
\hline B. firmus & Ettoumi et al. (2013) \\
\hline B. fusiformis & Wahyudi et al.(2010) \\
\hline B. licheniformis & $\begin{array}{l}\text { Tendulkar et al.(2006), Gomaa and Momtaz.(2006), Azokpota et } \\
\text { al. (2007), Xio et al. (2009), Ettoumi et al.,(2013) }\end{array}$ \\
\hline B. mojavensis & Sihem et al.,(2011), Youcef-ali et al.,(2014) \\
\hline B. mycoides & Athukorala et al.,(2009), Sarangi et al., (2009) \\
\hline B. pumilus & $\begin{array}{l}\text { Wulff } \text { et al., (2002), Matarante } \text { et al.,(2004), Parvathi } \text { et al., (2009), } \\
\text { Ettoumi } \text { et al., (2013), Moghaddam } \text { et al.,(2014) }\end{array}$ \\
\hline B. simplex & Gomaa and Momtaz. (2006) \\
\hline B. subtilis & $\begin{array}{l}\text { Wulff et al., (2002), Matarante et al., (2004), Azokpota et } \\
\text { al.,(2007), Kang Cheng } \text { et al., (2009), Athukorala } \text { et al.,(2009), } \\
\text { Sarangi et al., (2009), Wahyudi } \text { et al., (2010), Xia } \text { et al., (2011), } \\
\text { Sihem et al., (2011), Ettoumi et al.,(2013), Yap Chin Ann.(2013), } \\
\text { Youcef-ali et al.,(2014), Oliveira } \text { et al.,(2014), Wei } \text { et al., (2014) }\end{array}$ \\
\hline B. thuringiensis & $\begin{array}{l}\text { Hill et al., (2004), Reddy et al.,(2009), Yap Chin Ann. (2013), } \\
\text { Zahner et al., (2013) }\end{array}$ \\
\hline B.weihenstephanensis & Biswas and Das.(2011) \\
\hline B.subtilis & Tamalika Sarangi (2014) \\
\hline
\end{tabular}

\section{References}

Absalon, S.C., M. M.del, C.O. Mosqueda, M.M.M. Pacheco, R.F. Rodriguez, M. Govindappa, G. Santoyo. 2012. Isolation and molecular characterization of a novel strain of
Bacillus with antifungal activity from the sorghum rhizosphere. Genetics and Molecular Res., 67: 210-221.

Athukorala, Y., W.K. Jung, T. Vasanthan, Y.J. Jeon. 2006. An anti-coagulative polysaccharide from an enzymatic hydrolysate of Ecklonia cava. 
Carbohydr. Polym., 66: 184-191.

Azokpota, P., P.L. Moller, J.D. Hounhouigan, M. Jakobsen. 2007. Biodiversity of predominant Bacillus isolated from afitin, iru and sonru at different fermentation time. Int. J. Biol. Chem. Sci., 1(3): 211-222.

Biswas, S., S. Das. 2011. Peerless Hospital and B. K. Roy Research Centre, Dept. of Microbiology, Kolkata, WB/IN.

Ettoumi, B., A. Guesmi, L. brusetti, S. Borin, A. Najjari, A. Boudabous and A. Cherif. 2013. Microdiversity of deep-sea Bacillales isolated from tyrrhenian sea sediments as revealed by ARISA, $16 \mathrm{~S}$ rRNA gene sequencing and BOX-PCR fingerprinting. Microbes Environ., 28(3): 361-369.

Gomaa, O.M., O.A. Momtaz. 2006. 16S rRNA characterization of a Bacillus isolate and its tolerance profile after subsequent subculturing. Arab J. Biotechnol., 10(1): 107-116.

Hill, K. K., O. Lawrence, L. Ticknor, J.J. Paul. 2004. Fluorescent amplified fragment length polymorphism analysis of Bacillus anthracis, Bacillus cereus and Bacillus thuringiensis isolates. Appl. Environ. Microbiol., 70(2): 1068-1080.

Hung, P.Q., K. Annapurna. 2004. Isolation and characterization of endophytic bacteria in soybean (Glycine sp.). Omonrice. 12: 92-101.

Kang, S.M., J.Y. Min, Y.D. Kim, C.S. Karigar, S.W. Kim, G.H. Goo and M.S. Choi. 2009. Effect of biotic elicitors on the accumulation of bilobalide and ginkgolides in

Ginkgo biloba cell cultures. J. Biotechnol., 139: 84-88.

Lisboa, M. P., D. Bonatto, D. Bizani, J.A.P. Henriques, A. Brandelli. 2006. Characterization of a bacteriocin like substance produced by Bacillus amyloliquefaciens isolated from the Brazilian Atlantic Forest. Intl. Microbiol., 9: 111-118.

Manikandan, S., K. Muthuselvam. 2014. Isolation and characterization of phosphobacterial isolates from bhendi rhizosphere soils of Cuddalore district. Indian Streams Res. J., 4(5): 87-93.

Matarante, A., F. Baruzzi, P. S.Cocconcelli and M. Morea. 2004. Genotyping and toxigenic potential of Bacillus subtilis and Bacillus pumilus strains occurring in industrial and artisanal cured sausages. Appl. Environ. Microbiol., 70(9): 5168.

Moghaddam, M.R., S.B. Ravari and H. Rouhani. 2014. The nematicidal potential of local Bacillus species against the root-knot nematode infecting greenhouse tomatoes. Biocontrol Sci. Technol., 24(3): 27929.

Nagesh, M., R. Asokan and K.S. Mohan. 2005. Partial characterization of novel nematicidal toxins from Bacillus cereus and their effect on root knot nematode Meloidogyne incognita (Kofoid and White) Chitwood. J. Biol. Control, 19(1): 65-70.

Oliveira, A., J. Dobereiner J. Baldani. 2014. The effect of inoculating endophytic N2-fixing bacteria on micropropagated sugarcane plants. Plant Soil, 242: 205215.

Parvathi, A., K. Krishna, J. Jose, N. Joseph and S. Nair. 2009. Biochemical and molecular characterization of Bacillus pumilus isolated from coastal environment in Cochin, India. Brazilian J. Microbiol., 40: 269-275.

Rangaswami, G., D.J. Bagyaraj. 1993. Agricultural Microbiology II Edition. Prentice Hall, India, 214p

Raton, T.M.O., R. Yano, O.R. Gamez, E.I.S. Floh, M.J.S. Diaz and H.R. Barbosa. 
2012. Isolation and characterisation of aerobic endospore forming Bacilli from sugarcane rhizosphere for the selection of strains with agriculture potentialities. World J. Microbiol. Biotechnol., 28: 1593-1603.

Reddy, D.M., D. Paul, H. K. Reddy and G. Reddy. 2009. Characterization and identification of Bacillus cereus GMHS: An efficient 2-picoline degrading bacterium. Int. $J$. Integrative Biol., 5(3): 187.

Sarangi, N.P., W.G. Dilantha Fernando and Y. Khalid Rashid. Identification of antifungal antibiotics of Bacillus species isolated from different microhabitats using polymerase chain reaction and MALDI-TOF mass spectrometry. Canadian J. Microbiol., 55(9): p 1029.

Sihem, Ben Maachia, R., Errakhi, R. Mathieu, M. Chérif, A. Lebrihi. 2011. Identification and partial characterisation of antifungal and antibacterial activities of two Bacillus sp. strains isolated from salt soil in Tunisia. African J. Microbiol. Res., 13: 1599-1608.

Tamalika Sarangi. 2014. Utilization of antinemic or antimicrobial peptide genes associated with Bacillus spp. in the management of root knot nematode Meloidogyne incognita (Kofoid and White, 1919) Chitwood, 1949 on

Tomato (Solanum lycopersicum Mill). Ph.D dissertation, Tamil Nadu Agricultural University, Coimbatore, Tamil Nadu, India. P.371.

Tendulkar, S.R., Y.K. Saikumari, V. Patel, S. Raghotama, T.K. Munshi, P. Balaram and B.B. Chattoo. 2007. Isolation, purification and characterization of an antifungal molecule produced by Bacillus licheniformis BC98 and its effect on phytopathogen Magnaporthe grisea. J. Appl. Microbiol., 103: 23312339.

Vetrivelkalai, P., M. Sivakumar and E. I. Jonathan. 2010. Biocontrol potential of endophytic bacteria on Meloidogyne incognita and its effect on plant growth in bhendi.

J. Biopesticides., 3(2): 452-457.

Wahyudi, A.T., J. P. Bramantyo and N. R. Mubarik. 2010. Diversity of antifungal compoundsproducing Bacillus spp. isolated from rhizosphere of soybean plant based on ARDRA and 16S rRNA. J. BioSci., 17(3): 145-150.

Wang, W., M. Sun. 2008. Phylogenetic relationship between Bacillus species and related genera inferred from 16s rDNA sequences. Brazilian $J$. Microbiol., 40: 505-521.

Wei, G., J.W. Kloepper, S. Tuzun. 2014. Induced systemic resistance to cucumber diseases and increased plant growth by plant growthpromoting rhizobacteria under field conditions. Phytopathol., 86: 221-224.

Wulff, E.G., C.M. Mguni, K. MansfeldGiese, J. Fels, M. Lübeck and J. Hockenhull. 2002. Biochemical and molecular characterization of Bacillus Amyloliquefaciens, B. subtilis and $B$. pumilus isolates with distinct antagonistic potential against Xanthomonas campestris pv. campestris. Plant Pathol., 51: 574584.

Xiao, Z., P. Xu. 2009. Acetoin Catabolism and Acetylbutanediol formation by Bacillus pumilus in a Chemically Defined Medium. PLOS ONE, 4(5): 5627-5635.

Xia, Y., S. Xie, X. Ma, H. Wu, X. Wang and X. Gao. 2011. The purL gene of Bacillus subtilis is associated with nematicidal activity. FEMS Microbiol 
Lett., 322: 99-107.

Yap Chin Ann. 2012 . Screening for nematicidal activities of Bacillus species against root knot nematode (Meloidogyne Incognita), Research and Development Division, Malaysian Pepper Board. p 86.

Youcefali, M., N. K. Chaouche, L. Dehimat, I. Bataiche, M. Karaali, H. Cawoy and P.Thonart. 2014. Antifungal activity and bioactive compounds produced by
Bacillus mojavensis and Bacillus subtilis. African J. Microbiol. Res., 8(6): 476-484.

Zahner, V., A.C. Telles de Carvalho e Silva and I. de Filippis. 2013.Extended genetic analysis of Brazilian isolates of Bacillus cereus and Bacillus thuringiensis. Mem Inst Oswaldo Cruz., 108(1): 65-72.

\section{How to cite this article:}

Tamalika Sarangi and S. Ramakrishnan. 2016. A Review on Identification of Bacillus spp. using Molecular Characterization. Int.J.Curr.Microbiol.App.Sci. 5(7): 126-130.

doi: http://dx.doi.org/10.20546/ijcmas.2016.507.011 